\title{
METFORMIN TREATMENT IN INSULIN RESISTANT POLYCYSTIC OVARIES PATIENTS
}

\author{
Seham El Berry and Ahmed E. Mansour \\ Department of Obstetrics \& Gynecology, \\ Benha Faculty of Medicine
}

\section{ABSTRACT}

Objectives: To know the incidence and characters of insulin resistance (IR) in polycystic ovarics (PCO) paticnts, and the efficacy of metformin treatment for induction of ovulation compared to clomiphene citratc (CC); also the effect of metformin on the clinical, biochemical and hormonal fcatures of the patient would be evaluated.

Design : A prospective, blind, controlled study.

Setting : Outpatient infertility clinic, Benha University Hospital.

Subjects : Sixty infertile PCO patients.

Methods: The body mass index (BMI), the hirsutism and the acne scores, the fasting blood glucose, the fasting serum insulin and serum testosterone levels werc measured for every patient. A ratio of lasting blood glucose to fasting serum insulin (G/I) of less than $4.5 \mathrm{mg} / 10^{-4}$ untis was considered IR. Insulin resistant patients were randomly divided into thrce groups and treated for three cycles. The first group was treated with $\mathrm{CC}+$ metformin, the second with placebo + metformin and the third with $\mathrm{CC}+$ placebo.

Main outcome measures: The ovulation and pregnancy rates with metformin treatment compared to $\mathrm{CC}$.

Results : IR is present in about $86.6 \%$ of PCO patients. They are characterized by having higher BMI, fasting serum insulin and scrum testosterone levles, than non IR patients. Treatment with $\mathrm{CC}+$ metformin results in higher ovulation and pregnancy rates compared to that obtained with $\mathrm{CC}$ alone.

Conclusions : IR must be diagnosed in PCO patients. Induction of ovulation with $\mathrm{CC}+$ metformin results in higher ovulation and pregnancy rates. In contrast to $\mathrm{CC}$, the longer the duration of metformin treatment, the better are the results.

\section{INTRODUCTION}

Polycystic ovaries are a common endocrine disorder affecting up to $10 \%$ of women at the reproductive age ${ }^{(1)}$. The manifestations of the disease are variable, but the keystone for diagnosis is a patient complaining of oligomenorrhea and infertility, an ultrasound appearance of polycystic ovaries and an elevated serum LH and LH/FSH ratio. Other findings include obesity, hirsutism, acne, and elevated serum androgen levels.

In recent years, insulin resistance with compensatory hyperinsulinemia and increased risk of glucose intolerance are well recognized abnormal laboratory findings in $\mathrm{PCO}$ patients ${ }^{(2)}$.

Different investigators showed that hyper- insulinemia causes increases in serum androgen level by augmenting abnormal ovarian androgen secretion $^{(3,4)}$.

Clomiphene citrate is the drug of choice for induction of ovulation in PCO patients, however, about $25 \%$ of patients are resistant to $\mathrm{CC}^{(5)}$. Hyperinsulinemia and hyperandrogenemia are thought to be causative factors,

Metformin is a biguanide oral anti hyperglycemic drug which improves insulin sensitivity and lowers blood glucose and serum insulin levels ${ }^{(6)}$. Treatment of insulin resistant PCO patients with metformin combined with $\mathrm{CC}$ has been claimed to result in higher ovulation and pregnancy rates. 


\section{AIM OF THE WORK}

The aims of this work was:

1. To detect the incidence and characters of IR in PCO patients.

2. To compare between metformin and clomiphene citrate treatments for induction of ovulation in PCO cases.

3. To evaluate the effects of metformin treatment on the clinical, biochemical and hormonal features of the patients.

\section{MATERIALS \& METHODS}

The study was done at the outpatient infertility clinic of Benha university hospital during the period from January 2002 to June 2004, and included sixty $\mathrm{PCO}$ patients complaining of infertility and oligomenorrhea. Vaginal US showed enlarged ovaries containing 10 or more sub capsular cysts, $2-8 \mathrm{~mm}$ in diameter, arranged around echo dense stroma, and the laboratory investigations revealed elevated serum $\mathrm{LH}$ and LH/FSH ratio.

The body mass index (BMI), the hirsutism score $^{(7)}$ and the acne score ${ }^{(8)}$ were reported for every patient then the following laboratory investigations were done after an overnight fast:

a- The fasting and the 2-hours post prandial blood glucose level using the glucose oxidase technique. Normal fasting value $=70-110 \mathrm{mg} / \mathrm{dl}$ and 2-hours post prandial value $=140-145 \mathrm{mg} / \mathrm{dl}$. Higher values were further investigated by oral glucose tolerance test. Patients who proved to be diabetic were excluded from the study.

b,c- The fasting serum insulin and serum testosterone levels by the chemilumeniscence immunoassay (Elecsys) method using Roche diagnostics, Gmbh, D. 68298, Manheim, Germany. Normal value for serum insulin $=2-25 \mu \mathrm{IU} / \mathrm{ml}$ and for serum testosterone $=0.1-0.8 \mathrm{ng} / \mathrm{ml}$.

A ratio of fasting blood glucose to fasting serum insulin (G/I ratio) of less than $4.5 \mathrm{mg} / 10^{-4}$ unit was considered insulin resistance (IR) ${ }^{(9)}$.

IR patients were randomly allocated for induction of ovulation with one of the following regimens for three cycles:

1. CC $100 \mathrm{mg}$ daily from cycle day $5-9+$ metformin $1500 \mathrm{mg}$ daily through out the cycle.

2. Placebo from cycle day $5-9+$ metformin 1500 mg daily through out the cycle.

3. CC $100 \mathrm{mg}$ daily from cycle day $5-9+$ placebo through out the cycle.

Vaginal US was done on cycle day 12 , if the diameter of the leading follicle was $18 \mathrm{~mm}$ or more, ovulation was considered impending and 10.000 IU hCG was given IM, and sexual intercourse advised in next days. If the follicle diameter was less than $18 \mathrm{~mm}$, vaginal US was repeated on cycle days 14,16 and 18 . If the diameter was still below $18 \mathrm{~mm}$ the cycle was considered a failure of ovulation and hCG was not given.

After three treatment cycles, the ovulation and pregnancy rates were calculated, and the effect of metformin treatment on the BMI, the hirsutism and the acne scores, the fasting blood glucose, the fasting serum insulin and serum testosterone levels were recorded.

\section{Statistical Methods :}

Results were statistically analyzed using the mean, the standard deviation, the student-t test and the paired-t test. The result was considered significant if its $P$ value was $<0.05$. 


\section{RESULTS}

Sixty PCO patients were studied, 52 patients $(86.6 \%)$ had a fasting blood glucose level / fasting serum insulin level less than $4.5 \mathrm{mg} / 10^{-4}$, which is consistent with IR, while 8 patients were non IR $(13.4 \%)$.

Table I: shows that the mean BMI, fasting serum insulin, and serum testosterone levels were significantly higher in IR patients $(\mathrm{P}<0.05-0.001)$.

Table II, III and IV: show that the ovulation and pregnancy rates increase in the second and third treatment cycles in patients who received metformin with $\mathrm{CC}$ or metformin alone, while both parameters decreased in patients who received CC alone.

Table V: shows that the highest ovulation and pregnancy rates were in the $\mathrm{CC}+$ metformin group, followed with metformin + placebo group, while the lowest were in the $\mathrm{CC}+$ placebo group.

Table VI: shows that after metformin treatment there was a significant decrease in fasting serum insulin and serum testosterone levles $(P<0.01)$, while there was no change in the BMI, hirsutim and acne scores and the fasting blood glucose level.

\section{DISCUSSION}

Insulin resistance (IR) is defined as a clinical state in which a normal or elevated insulin level produces an impaired biological response ${ }^{(10)}$. There are different tests to diagnose IR, but the easiest and mostly used is the ratio of fasting blood glucose to fasting serum insulin level $(\mathrm{G} / \mathrm{I})^{(9)}$ of less than $4.5 \mathrm{mg} / 10^{-4}$.

Not all PCO patients have IR. In our study 86.6\% of patients had IR due to the increase in serum insulin. The exact pathogenesis of hyperinsulinemia in $\mathrm{PCO}$ patients remains undetermined. Some authors ${ }^{(11)}$ found that there was no decrease in insulin receptors number or affinity in PCO patients. Others ${ }^{(12)}$ mentioned that IR may be a consequence of obesity, as adipose tissue produces tumor necrosis factor $\alpha$ (TNF $\alpha$ ) which exerts inhibitory effects on insulin action. A post receptor defect in insulin action which is manifested by decrease in insulin receptors phosphorylation following insulin binding was proposed $^{(13)}$

Other causes of hyperinsulinemia in PCO patients could be increased pancreatic secretion of insulin resulting from genetic mutation ${ }^{(14)}$ or a defect in glucose transport ${ }^{(15)}$.

In our study, serum testosterone level was significantly higher in IR, $\mathrm{PCO}$ patients $(\mathrm{P}<0.05)$. This result agrees with that reported by most authors ${ }^{(16,17)}$. Hyperinsulinemia causes increased ovarian androgen secretion through different mechanisms :

Insulin by acting via its own receptors ${ }^{(18)}$ or via insulin like growth factor-1 (IGF-1) receptors ${ }^{(19)}$ stimulates ovarian production of androgens. Others ${ }^{(20)}$ suggested that insulin by increasing IGF-1 increases the effect of lutenizing hormone on ovarian androgen production. An association between hyperinsulinemia and increased adrenal androgen secretion was suggested ${ }^{(21)}$ while other authors $^{(22)}$ found that insulin inhibit hepatic production of sex hormone binding globulin, thus increasing free androgen level.

Hirsutism and acne are markers for increased androgen production, but it does not occur in all hyperandrogenic PCO patients. In our study, there was no significant difference between the incidence of either hirsutism or acne in IR and non IR patients.

In the present study, the BMI was significantly higher in IR than in non IR patients $(\mathrm{P}<0.05)$; this 
result agrees with that reported by prelevic (23) who found that IR was present in $30 \%$ of slim and in $75 \%$ of obese women with PCO.

In our study, the highest ovulation and pregnancy rates were in patients treated with $\mathrm{CC}+$ metformin followed by metformin then by $\mathrm{CC}$. This result agrees with that reported by several authors $(24,25,26,27)$. On the other hand, some authors ${ }^{(28,29)}$ failed to find any beneficial effect of metformin treatment. An interesting result in our study was that the ovulation and pregnancy rates increased with longer duration of metformin treatment, in contrast with $\mathrm{CC}$ alone treatment, where both parameters decreased. This result was not reported in previous studies.

In the present study, there were a significant decrease in fasting serum insulin and serum testosterone levels after metformin treatment compared to pre treatment levels. These results agreed with that reported by several studies $(30,31,32,33)$. On the other hand, some authors did not find any decrease in serum insulin and serum testosterone levels after metformin therapy ${ }^{(34,25)}$. This discrepancy in results may be due to inclusion of both IR and non IR, PCO patients in other studies, or due to different dose and duration of metformin treatment.

In our study there was no change in the BMI after metformin treatment, a result which agrees with that reported by Morin-papunen et al and Ehrmann et al ${ }^{(35,34)}$. However, other authors reported a significant decrease in the BMI after metformin treatment ${ }^{(32,25)}$. This discrepancy in results may be due to differences in the duration and dose of metformin treatment or in the definition of obesity of either a BMI $>25$ or 27 .

the mechanisms by which metformin affect weight, are not fully established. A decrease in serum insulin with consequent decrease in appetite and lipogenesis, or the decrease in the dietary intake associated with the gastrointestinal effect of the drug was suggested ${ }^{(36)}$.

In our study, hirsutism and acne were not improved after metformin treatment in spite of significant decrease in serum testosterone levle, a result which agreed with that reported by other $(34,32)$. On the other hand a decrease in hirsutism and acne scores after 12 weeks of metformin treatment was reported by Kolodziejczyk et al ${ }^{(8)}$, The degree of hirsutism associated with PCO does not correlate only with the concentration of circulating androgens but also on the genetic sensitivity of the hair follicle ${ }^{(37)}$.

\section{CONCLUSIONS}

Insulin resistance must be diagnosed in PCO patients. treatment with metformin decreases serum insulin and serum testosterone levels. Combined $\mathrm{CC}+$ metformin results in higher ovulation and pregnancy rates. In contrast with $\mathrm{CC}$, the longer the duration of metformin treatment, the better are the results.

\section{REFERENCES}

I- Knochenhaurer ES, Key TJ and Kahsar-Miller M: Prevelance of polycystic ovaries syndrome in unselected black and white women of the southeastern United States: A prospective study. J Clin Endocrinol Mctam, 1999; 83; 3078-3082.

2- Franks S. : Polycystic ovary syndrome. N. Engl. J. Med, 1995; 333: 853-861.

3- Martikainen $H$, Salmela $P$, Nuojua-Huttunen $S$, et al.,: Adrenal steroidogenesis is related to insulin in hyperandrogenic women . Fertil. Steril. 1996; 66: 564-570.

4- Dunaif $\mathrm{A}$ : Insulin resistance and polycystic ovary syndrome: mechanism and implication for pathogenesis. Endocr. Rev. 1997; 18: 774-800.

5- Hamilton-Fairly D: Polycystic ovary syndrome. In ASCHR, Studd. J. cditors Annual Progress in reproductive medicine, 1993; pp 71. 
6- Perricl $G$ : Mechanism of metformin action in NIDDM. Diabetes Metab. Rev. 1995; 11: 43-50.

7- Ferriman D and Gallway JD: Clinical assessment of body hair growth in women. J. Clin. Endocrinol. Metab. 1961; 21: 1440-47.

8- Kolodriejczyk B, Duleba A. I. Spaczynski R. Z et al.,: Metformin therapy decreases hyperandrogenism and hyperinsulinemia in women with polycystic ovary syndrome. Fertil. Steril. 2000; 73: 1149-1154.

9- Legro RS, finegood D and Dunaif A : A fasing glucose to insulin ratio is a useful measure of insulin sensitivity in women with polycystic ovary syndrome. J. Clin. Endocrinol. Metab. 1998; 83(3): 2694.

10- Abate N: Insulin resistance and obestiy. The role of fat distribution pattern. Diabetes Carc. 1996; 19: 292-294.

11- Change RJ, Nakamura RJ, Judd HL et al.,: Insulin resistance in non-obese patients with polycystic ovarian discase. J. Clin. Endocrinol, Metab. 1983; 57: 356-359.

12- Hotamisligi CS and Spiegelman BM: Tumor necrosis factor alpha: A key component of obestiy-diabetes link. diabetes. 1994; 43: 1271-1278.

13- Dunaif A., Xia J, Book CB cl al.,: Excessive insulin receptor serine phosphorylation in cultured fibroblasts and in skeletal muscle: A potential mechanism for insulin resistance in the polycystic ovary syndrome. J. Clin. Invest. 1995; 96: 801-810.

14- Waterworth DM, Bennett ST, Gharani N et al,,: Linkage and association of insulin gene under regulatory polymorphisim with polycystic ovary syndrome. Lancet. 1997; 349: 986-990.

15- Shepart PR, Withers DJ and Siddle J: Phosphoinositide 3-kinase: the key switch mechanism in insulin signaling. Biochem. J. 1998; 333: 47I-490.

16- Nahum R, Thong $\mathrm{KJ}$ and Hillier SC : Metabolic regulation of androgen production of human theca cells in vitro. Hum. Reprod. 1995; 10: 75-81.

17- Nestler JE, Barlasani CO, Matt DW, et al.,: Suppression of serum insulin by diazoxide reduces testosterone levels in obese women with polycystic ovarian syndrome. J. Clin. Endocrinol. Metab 1989; 68: $1027-1032$.

18- Barbieri RL, Makris A, and Ryan KJ : Effects of insulin on steroidogenesis in cultured procine ovarian theca. Fertil. Steril. 1983; 40: 237-241.
19- Poretsky L, glover B, Laumas V, et al., the effects of experimental hyperinsulinemia on stcroid sccretion, ovarian (1251) insulin binding and ovarian (1251) insulin-like growth factor I binding int he rat. Endocrinology. 1988; 122: 581-585.

20- Cara JF and Rosenfield RL: Insulin-like growth factor I and insulin potentiate luteinizing hormone induced androgen biosynthesis by rat ovarian theca-interstitial cells. Endocrinology. 1988; 123: 733-739

21- Azziz R, Bradley ELJr, Potter HD, et al,, chronic hyperinsulinemia and the adrenal androgen response to acute corticotropin (1-24) stimulation in hyperandrogenic women. An. J. Obstet. Gynccol. $1995 ; 172: 125 !-1256$.

22- Nestler JE, Pores LP and Matt DW : A direct effect of hyperinsulinemia on serum sex hormone binding globulin levels in obese women with polycystic ovary syndrome., J. Clin. Endocrinol. Mctab. 1991; $72: 83-84$

23- Prelevic GM: Insulin resistance in polycystic ovary syndrome. Curr Opin Obstet Gynecol. Jun; 1997; 9 (3): 193-201

24- Batukan C and Baysal B: Metformin improves ovulation and pregnancy rates in patients with polycystic ovary syndrome. Arch. Gynecol. Obstet. 2001; 265: 124-127.

25- Vandermolen DT, Ratts VS, Evans WS, et al.,; Meftformin increases the ovulatory rate and pregnancy rate in patients with polycstic ovary syndrome who arc resistant to clomiphene citrate alone. Fertil. Steril. 2001; 75 : $310-315$.

26- Heard MJ, Picrce A, Carson SA, et al.,: Pregnancies following use of metformin for ovulation induction in patients with polycystic ovary syndrome. Fertil. Steril 2002; 77: 669-673.

27- Kowak M, Caliskan E, Simsir C, et al.,: Metformin therapy improves ovulatory rates, cervical scores, and pregnancy rates in clomiphene citratc resistant women with polycystic ovary syndrome. Fertil. Steril. 2002; 77: 101-106.

28- De Lco V, La Marca $\Lambda$, Ditt A, et al,: Effects of metormin on gonadotropin-induced ovulation in women with polycystic ovary syndrome. Fertil. Steril. 1999; 72: 282-285.

29- Yaradli H, Yildiz BO, Demirol A, et al.,: Co-administration of metformin during rFSH 
trcatment in patients with clomiphene citrate-resistant polycystic ovarian syndrome: a prospective randomized trial. Hum. reprod. 2002; 17: 289-294.

30- Diamanti-Kandarakis E, Kouli C, tsianateli T, ct al., Therapeutic effects of metformin on insulin resistance and hyperandrogenism in polycystic ovary syndrome. Eur. J. Endocrinol. 1998; 138: 269-274.

31 - Nestler JE, Jakubowicz DJ, Evans WS, et al.,: Effect of metformin on spontaneous and clomiphene induced ovulation in the polycystic ovary syndrome. N Engl. J. Med, 38: 1876-1880.

32- Moghetti P, Cascilo R, Negri C, et al.,: Metformin effects on clinical features, endocrine and metabolic profiles, and insulin sensitivity in polycystic ovary syndrome: A randomized, double blind, placebo controlled 6-months trial, followed by open, long-term clinical evaluation. J. Cli . Endocrinol. Metab. 2000; 85: 139-146.
33- Kriplani A and Agarwal N: Effects of metformin on clinical and biochemical parameters in polycystic. ovary syndrome. J Reprod Med. 2004; 49(5): $361-7$.

34- Morin-Papunen LC, Koivune RM, Tomas C, et al.,: Decreased serum leptin concentrations during metformin therapy in obese woemn with polycystic ovary syndrome. J. Clin. Endocrinol. Metab. 1998; 83: $2566-2568$.

35- Ehrmann DA, Cavaghan M, Imperial J, et al.,: Effects of metformin on insulin action and ovarian steroidogencsis in women with polycystic ovary syndrome. J. clin. Endocrinol. Metab. 1997; 82: 524-530.

36- mWilliam's G : Management of NIDDM. Lancet. 1994; 95-100.

37- Speroff L, Robert HG and Nathane GK: Clinical gynecologic endocrinology and infertility $\left(6^{\text {th }}\right.$ edition). Baltimore, Maryland, Williams and Wilkins. 1999; P 47.

Table I : Clinical, biochemical and hormonal features of IR and non-IR PCO patients.

\begin{tabular}{|l|c|c|c|c|c|c|}
\hline \multirow{2}{*}{ Features } & \multicolumn{2}{c|}{ IR $\mathbf{n = 5 2}$} & \multicolumn{2}{c|}{ non IR n = 8 } & \multirow{2}{*}{ t } & P \\
\cline { 2 - 7 } & Mean & $\pm \mathbf{S . D}$ & Mean & $\pm \mathbf{S . D}$ & & \\
\hline BMI & 30.20 & 3.30 & 27.90 & 2.88 & 1.42 & $<0.05$ \\
\hline Hirsutism score & 8.66 & 0.26 & 7.98 & 1.77 & 1.08 & N.S \\
\hline Acne score & 1.34 & 0.20 & 1.32 & 0.03 & 0.70 & N.S \\
\hline Fasting blood glucose & 86.36 & 4.64 & 85.16 & 2.44 & 1.12 & N.S \\
\hline Fasting serum insulin & 25.60 & 3.32 & 16.17 & 2.52 & 9.40 & $<0.001$ \\
\hline G/I ratio & 3.38 & 0.31 & 5.27 & 0.51 & 10.6 & $<0.001$ \\
\hline Serum testosterone & 1.98 & 0.06 & 1.88 & 0.03 & 7.70 & $<0.001$ \\
\hline
\end{tabular}

Table II : Ovulation and pregnancy rates with $\mathrm{CC}+$ metformain in the three treatment cycles.

\begin{tabular}{|c|c|c|c|c|c|}
\hline \multirow{2}{*}{ Cycle } & \multirow{2}{*}{ No. } & \multicolumn{2}{|c|}{ Ovulation } & \multicolumn{2}{|c|}{ Pregnancy } \\
\hline & & No. & $\%$ & No. & $\%$ \\
\hline $1^{s t}$ & 18 & 12 & 66.7 & 4 & 22.2 \\
\hline $2^{\text {nd }}$ & 14 & 10 & 71.4 & 4 & 28.6 \\
\hline $3^{\text {rd }}$ & 10 & 8 & 80.0 & 3 & 30.0 \\
\hline Total & 42 & 30 & 71.4 & 11 & 26.2 \\
\hline
\end{tabular}


Table III : Ovulation and pregnancy rates with placebo + metformin in the three treatment cycles.

\begin{tabular}{|l|c|c|c|c|c|}
\hline \multirow{2}{*}{ Cycle } & \multirow{2}{*}{ No. } & \multicolumn{2}{|c|}{ Ovulation } & \multicolumn{2}{c|}{ Pregnancy } \\
\cline { 3 - 6 } & & No. & $\%$ & No. & $\%$ \\
\hline $1^{\text {st }}$ & 17 & 6 & 35.3 & 1 & 5.9 \\
\hline $2^{\text {nd }}$ & 16 & 6 & 37.5 & 2 & 12.5 \\
\hline $3^{\text {rd }}$ & 14 & 6 & 42.9 & 2 & 14.3 \\
\hline Total & $\mathbf{4 7}$ & $\mathbf{1 8}$ & $\mathbf{3 8 . 3}$ & $\mathbf{5}$ & $\mathbf{1 0 . 6}$ \\
\hline
\end{tabular}

Table IV : Ovulation and pregnancy rates with $\mathrm{CC}+$ placebo in the three treatment cycles.

\begin{tabular}{|l|c|c|c|c|c|}
\hline \multirow{2}{*}{ Cycle } & \multirow{2}{*}{ No. } & \multicolumn{2}{|c|}{ Ovulation } & \multicolumn{2}{c|}{ Pregnancy } \\
\cline { 3 - 6 } & & No. & $\%$ & No. & $\%$ \\
\hline $1^{\text {st }}$ & 17 & 9 & 29.4 & 1 & 5.9 \\
\hline $2^{\text {nd }}$ & 16 & 4 & 25.0 & 0 & 0 \\
\hline $3^{\text {rd }}$ & 16 & 3 & 18.8 & 0 & 0 \\
\hline Total & $\mathbf{1 6}$ & $\mathbf{1 2}$ & $\mathbf{2 6 . 1}$ & $\mathbf{1}$ & 2.2 \\
\hline
\end{tabular}

Table V : Cumulative ovulation and pregnancy rates per cycle in the three treatment groups of IR, PCO patients.

\begin{tabular}{|l|c|c|c|c|c|}
\hline \multirow{2}{*}{ Cycle } & \multirow{2}{*}{ No. } & \multicolumn{2}{c|}{ Ovulation } & \multicolumn{2}{c|}{ Pregnancy } \\
\cline { 3 - 6 } & & No. & $\%$ & No. & $\%$ \\
\hline CC + metformin. & 42 & 30 & 71.4 & 11 & 26.2 \\
\hline Placebo + metformin. & 47 & 18 & 38.3 & 5 & 10.6 \\
\hline CC + placebo & 46 & 12 & 26.1 & 1 & 2.2 \\
\hline
\end{tabular}


Table VI : Effects of metformin treatment on clinical, biochemical and hormonal features of IR, PCO patients $(n=35)$.

\begin{tabular}{|l|c|c|c|c|c|c|}
\hline \multirow{2}{*}{ Features } & \multicolumn{2}{c|}{ before ttt } & \multicolumn{2}{c|}{ After ttt } & \multirow{2}{*}{ Paired-t } & P \\
\cline { 2 - 7 } & Mean & \pm S.D & Mean & \pm S.D & & \\
\hline BMI & 29.16 & 2.16 & 28.87 & 1.18 & 1.71 & N.S \\
\hline Hirsutism score & 8.33 & 0.66 & 8.16 & 0.41 & 1.82 & N.S \\
\hline Acne score & 1.16 & 0.44 & 1.26 & 0.63 & 1.91 & N.S \\
\hline Fasting blood glucose & 84.98 & 3.18 & 82.77 & 3.22 & 1.78 & N.S \\
\hline Fasting serum insulin & 25.33 & 2.19 & 18.17 & 1.85 & 2.75 & $<0.01$ \\
\hline G/I ratio & 3.35 & 0.38 & 5.12 & 0.53 & 2.60 & $<0.01$ \\
\hline Serum testosterone & 1.30 & 0.30 & 0.99 & 0.20 & 2.88 & $<0.01$ \\
\hline
\end{tabular}

$\mathrm{tt} \mathrm{t}=$ treatment 